\title{
A Passion for Respect: On Understanding the Role of Human Needs and Morality
}

\begin{abstract}
:
In the present paper, we stress the importance of the concept respect in a wide variety of social settings and provide a working definition of this concept by emphasizing how respect relates to the act of communicating full recognition to other people on the dimensions of belongingness and morality. Subsequently, in two separate parts, we discuss why respect is so desired and valued. The first part looks at respect as a means to fulfil important human social concerns ("respect as a means to an end"). The second part looks at the potential moral underpinnings of respect and thus interprets "respect as an end in itself." Finally, it is suggested that both reasons to value respect explain respect effects as a function of the working selfconcept that is salient (i.e., pragmatic versus idealistic self).
\end{abstract}

Keywords: respect, needs, belongingness, self-esteem, morality

\section{Zusammenfassung:}

Im vorliegenden Beitrag unterstreichen wir die Bedeutung des Respektkonzepts für eine Vielzahl sozialer Situationen. Wir geben eine Arbeitsdefinition vor, in der wir betonen, dass Respekt die volle Anerkennung anderer Personen über Dimensionen der Zugehörigkeit und der Moral kommuniziert. Danach, diskutieren wir in zwei Abschnitten, warum Respekt begehrt und gewertschätzt wird. Der erste Abschnitt fokussiert auf „Respekt als ein Mittel zum Zweck", um wichtige menschliche soziale Belange zu erfüllen. Der zweite Teil fokussiert auf den möglichen moralischen Unterbau von Respekt und interpretiert „Respekt als ein Zweck in sich selbst“. Schließlich, wird vorgeschlagen, dass diese beiden Gründe Respekt wertzuschätzen die Effekte von Respekt im Sinne einer Funktionserfüllung des jeweils salienten Selbst-Konzeptes (also, ideales versus pragmatisches Selbst) erklären können.

Schlüsselwörter: Respekt, Bedürfnisse, Zugehörigkeit, Selbstwertgefühl, Moral

\section{Introduction}

Respect is a "buzz" word in our contemporary society. In our newspapers we daily read stories about football players who have to sit on the substitute bench and, in response, demand more respect from the coach and the club (even though they earn large amounts of money, regardless whether they play or not). In organizations, employees encounter situations in which they feel that they are not listened to and that their ideas and suggestions even are ignored. As a result, many of them may engage in acts of sabotage or leave the organization in a disappointed manner because they did not feel respected. In our close relationships, partners may show less commitment to the other and the relationship as a whole when they notice that their partner hardly devotes any attention to their needs and problems. In these situations it is often sighted " ... he or she does not respect me." 
These situations point out a concern that most people have experienced, that is, "Do others respect me or not?" Throughout our society (e.g. organizations, teams, close relationships, customer relationships etc.) there is an increasing demand for respect (Hill jr., 2000; O' Connell, 2000), leading people to ever-greater concerns about whether such respect has been granted. Moreover, as the examples above show, concerns for respect can in fact be found across a wide variety of situations. Indeed, our own experiences make clear that respect is valued in situations where we meet friends, in interactions with unknown others, and even so in economic exchanges in which outcomes and financial concerns drive the interaction and where one wishes to appear as a tough negotiator. As a matter of fact, Lax and Sebenius (1986, p. 74) noted that "negotiator's interests can go beyond the obvious and tangible" and they also noted that "take for example, the almost universal quest for social approval or the simple pleasure one derives from being treated with respect, even in a one-time encounter."

Thus, it is clear that in our social lives respect constitutes an important outcome that we wish others allocate to us. So, how do we conceptualize respect? In the present paper, we borrow from insights in recent social psychological research on respect. More precisely, in our view, respect signals a full recognition as a person, which holds the assumption that respect provides information about our status, prestige and a feeling of being accepted by others in our groups and community (De Cremer, 2002, 2003; De Cremer \& Tyler, 2005a,). ${ }^{2}$ In a way, respect among group members thus signals that you as a person are an equal to others (Simon, Lucken \& Stürmer, 2006). Moreover, we argue that feeling an equal in terms of status and belongingness also communicates that you are treated with the same dignity and moral worth as any other. This relates to the concept of respect as something that every human being has a claim to (as it makes us all dignified humans living in a moral community). As Kant (Hill, 2000, p. 64) noted, "it is a duty to respect others as human beings", so every human being is equal in the sense that they have equal worth and deserve equal respect.

Building on the above, this issue of feeling recognized (as a function of respect) therefore can be seen as reflecting two views of respect that suggest why we value respect so much. That is, respect is a concept that has the potential to (a) fulfil the needs of the person (such as belongingness and reputation) in his or her social life (i.e., "respect as a means to an end"), and (b) affirm the moral values that we wish to live by and which makes up for our moral community (i.e., "respect as an end in itself").

\section{Respect as a Means to an End: Serving the Human Needs of Belongingness and Reputation}

The "Respect as Intragroup Status" model (RIS; De Cremer \& Tyler, 2005b) explores how respect communicates intragroup information and which identity concerns are involved. The model poses that feeling recognized by others includes receiving a relational appreciation from those others. This happens in two ways. First, respect can be seen as a signal that one belongs to the group or community and second, that one is evaluated positively and has a positive status or reputation within this group or community. In other words, respect indicates that one is included in the group and that one has a good reputation in the eyes of fellow group members. These two aspects lead people 
to consider themselves as having a positive status within the own group or community. The RIS model emerged from the relational models of procedural justice (De Cremer \& Tyler, 2005c; Lind \& Tyler, 1988; Tyler \& Lind, 1992). According to these relational models, one important type of information that provides us with cues about our standing in our relationships with others is the fairness of procedures enacted by the group and its members. Research on procedural fairness has indeed shown that the use of fair procedures positively influences people's self-regard and identity (e.g., Koper, van Knippenberg, Bouhuijs, Vermunt, \& Wilke, 1993). The reason for this is that fair procedures communicate to people that they are perceived as having a respected position within the group. In other words, they feel recognized as a member having important relational value to the group. Therefore, in these relational models, respect is seen as an important indicator of intragroup status. In line with this proposition, research indeed shows that people's judgments about their standing within the group, and their associated feelings of self-regard, are enhanced when they receive respectful treatment by the group and its authorities (Boeckman \& Tyler, 2002; Tyler, Degoey, \& Smith, 1996). As such, respect is considered not as something that people simply intuit by themselves, but rather as a judgment that emerges from the treatment they receive from others.

Thus, respect informs people that they have a valued status in a relationship. But why is this so important for people? As argued before, the RIS model (De Cremer \& Tyler, 2005b) answers to this by posing that having a valued status in a relationship satisfices 1) the need to be belong and 2) the need to have a positive social reputation in the eyes of others. Respect specifically fulfils these needs.

Let us first address belongingness needs. Several lines of research point to the conclusion that people are social beings in that they use their relationships with other individuals or groups to define their social self (Aron \& Aron, 1986). A crucial aspect in this self-definitional process is that people pursue a sense of inclusion - a tendency that is believed to be inherent to human beings in general (Kurzban \& Leary, 2001). Research on the need to belong (e.g., Baumeister \& Leary, 1995; Gardner, Pickett, \& Brewer, 2000; Twenge, Baumeister, Tice, \& Stucke, 2001; Twenge, Catanese, \& Baumeister, 2002), indeed demonstrates that people are fundamentally motivated to be included in groups and relationships that they consider to be important to them. As a result, people are very attentive toward any type of relational information communicated by others, but particularly so when their need to belong is unfulfilled. The importance and pervasiveness of this need to belong has been shown by research demonstrating that a lack of positive social relationships has detrimental effects on the physical, cognitive and behavioral level (Baumeister \& Leary, 1995; Reis, Collins, \& Berscheid, 2000). For example, not feeling accepted by others influences well-being negatively, reinforces selective memory for socially relevant information and undermines intrinsic motivation (e.g., Berscheid \& Reis, 1998; Gardner, Gabriel, \& Diekman, 2000; Gardner, Pickett, \& Brewer, 2000), whereas fulfilling the need to belong positively influences cooperative behavior within groups (De Cremer \& Leonardelli, 2003).

With regard to the issue of respect, De Cremer and Tyler (2005a) have shown that need to belong affected the impact of receiving respect. When their concerns to belong were made salient, people showed stronger emotional reactions, were more cooperative, or more likely to exit the group. Moreover, De Cremer (2003a) further showed that the positive effect of respect on cooperation in pubic good dilemmas was mediated by feelings of belonginess. These findings support the notion that people value respect out 
of a concern to belong. Interestingly, these results are also in line with the relational equilibrium model (REM) which addresses the role of respect in leadership (see De Cremer, 2003b). According to REM, respect has a positive influence on leadership effectiveness because followers attend to relational information such as respect as a function of their individual belongingness needs and their sense of belongingness as signaled by their group membership at hand (in addition to a base rate or equilibrium independent of their belongingness needs).

The second result of receiving respect is that it fulfills our concern for a positive reputation. As early as the writings of James (1890), researchers acknowledge that one's identity is, at least partly, determined by one's social reputation. Indeed, because social evaluation is an important element in the process of constructing the self and identity, people are, by their very nature, motivated to obtain a positive image or reputation (see e.g., the extensive literature on people's public self-presentation skills; Baumeister, 1982; Leary, 2001). In fact, social reputations largely determine how one's behaviors are recognized and rewarded (e.g., Johnson, Erez, Kiker, \& Motowidlo, 2002). Reputation, then, is a prized possession to be protected or augmented because of its implications for the kind of person one is in both interpersonal as group settings. The powerful effects of social reputation in groups has, for example, been demonstrated by recent research showing that people can exhibit more cooperative behavior to confirm either their positive reputation or to allow them to obtain such a positive evaluation (e.g., De Cremer, Snyder, \& Dewitte, 2001).

With regard to the issue of respect, De Cremer and Tyler (2005a) have shown that reputation concerns affected the impact of receiving respect. When concerns for reputation were strong, respect affected people's emotional response and their self-esteem to a larger extent. This supports the notion that people value respect because respect caters to reputational concerns.

To summarize so far, the RIS model puts forward that respect communicates a valued intragroup status and in this way satisfices two important identity needs, that is, the search to belong and establish a favorable reputation. Of course, satisfying needs and social concerns leads people, in general, to feel better about themselves may thus influence their level of self-esteem. As a matter of fact, our idea that these two social concerns impact upon people's self-esteem aligns well with sociometer's theory's proposal that a vital function of self-esteem is to monitor and communicate to the individual the degree of social acceptance (Leary \& Baumeister, 2000). Thus, self-esteem reflects perceptions of inclusionary status (Gailliot \& Baumeister, in press).

This idea of impacting self-esteem is also very relevant to what happens within groups. In fact, recently, group research has begun to devote more attention to the role that members' self-esteem plays in terms of group functioning (e.g., McAllister \& Bigley, 2002). More precisely, in the last decade it has become increasingly clear that self-esteem is not only an important psychological need, but also an important economic need (Branden, 1998). That is, self-esteem plays a role in how people evaluate themselves and how efficacious they feel. These feelings, in turn, are of major (economic) importance in the process of how employees, at different levels in the organization, reason, decide, and regulate action. Moreover, research has also demonstrated that individuals with high and low self-esteem react differently toward conflict situations, and task interdependence, and perceive relationships with others in the group as serving different functions (Brockner, 1988; Duffy, Shaw, \& Stark, 2000; Leary \& Baumeister, 2000). 
What to conclude from this perspective of respect as a means to an end? This perspective advocates the use of respect as an important means to satisfy needs that help us to evaluate our standing within the group or community that one is a member of. However, this perspective also implies that respect addresses the satisfaction of an individual need and not necessarily a collective need. Indeed, it is the individual drive of need to belong and need for a favorable reputation that makes us so susceptible to information about respect. As such, it seems like individuals value respect within groups merely to fulfill their own individual needs rather than those of the group. Indeed, also Heuer, Penrod, Hafer, and Cohn (2002) noted that "people care about respect because of what it conveys about others' valuation of their worth as individuals rather than its group-based connotations". In a way, this observation may even signal a certain rise of individualism in group settings. That is, group members seem to be active participants that contribute to group life and productivity as a function of how they have been treated by the group (see also Simon \& Stürmer, 2003).

However, we also wish to argue that this individualistic view of why people value respect does not necessarily tell the whole story. We wish to emphasize that respect does not only have to be looked upon as an individual-based driven concept. Indeed, in the next section we adopt the second perspective of "respect as an end in itself". This perspective will make clear that respect is also something that can be endorsed out of more collective values.

\section{Respect as an End in Itself: Respect as a Gatekeeper of the Moral Community}

This second perspective suggests that respect can be seen as a value that we strive for, regardless of any individual or instrumental benefits. It implies the idea that we like to be respected because we feel that we should or ought to respect people, because it is an innate human value (and is thus not driven solely by personal desires). This idea aligns well with Kant and his categorical imperative (Hill, 2000, p. 39), which holds that moral behaviour is an end in itself because of "a rational moral requirement for everyone that is not based or conditional on its serving one's contingent personal ends."

Using this second perspective suggests that respect is not valued because out of personal needs that need to be satisfied, but because it is a universal law dictating that respect is an ought or even a moral duty. In this way, respect can be seen as a moral building stone or even gatekeeper for a moral and humanitarian community. From this point of view, the second perspective thus indeed treats respect as a community or collective-based value. As a matter of fact, as we know, communities and collectives fare well if it has principles guiding social behaviour. One important class of principles are those addressing ethical and moral issues.

Ethical principles tell us what's important and how we ought to treat other human beings; one important principle being to approach others in respectful ways (Miller, 2001). Thus, as ethical individuals we consider respect as something that is a duty and therefore we automatically submit to this ethical principle. As such, giving respect to others is something that should happen without any hesitation and cognitive delibera- 
tion. In fact, one may even argue that respect as an important ethical principle is hardwired and makes that we can live in a moral and humanitarian community.

Following from the above line of reasoning, we thus can say that the perspective "respect as an end in itself" suggests that the act of giving respect is a basic and moral undertaking that helps us to develop humanitarian and dignified social relationships, ultimately affirming the existence of a moral community. Such a moral community is regarded as relatively cohesive, because independent of talents, accomplishments, and social status, each person is to be regarded as having a special worth that we always must take into account. As such, this second perspective also shows again that respect can serve as "social glue" in our social lives.

If respect helps to build up this moral and humanitarian community, a subsequent assumption is that it should be internalized in such a way that we are willing to sacrifice our interests, maybe even our lives to ensure that respect is maintained or even reinforced. In fact, if respect is an internalized value then a violation of it should represent a threat to ethical principles and just world beliefs of all kinds, making that sacrificing behaviour will be evoked to affirm the presence of respect. Recent research on altruistic punishment supports the idea that people are willing to sacrifice for the existence of moral values such as respect. More precisely, this line of research has shown that people are indeed willing to incur personal costs to pursue morality and justice. That is, when observing an individual cheating on someone else, people are willing to punish this individual, even when they themselves were not harmed by the cheating and even when the punishment is costly for them (Fehr \& Fischbacher, 2003; Fehr \& Gächter, 2002). This line of research thus emphasizes the important argument that people are, beyond their self-interest, concerned with safeguarding moral and just behavior. In a similar vein, it can be suggested that respect is a moral value that we automatically share with others and therefore are willing to preserve at any (personal) cost.

Thus, respect can also represent an important value in itself because respect as an end in itself makes us dignified and ethical humans beings. Interestingly, if people can also value respect because of its moral connotations, then it may be very likely that respect as an end in itself will impact upon people's self-esteem as well. Indeed, research, for example, shows that people like to evaluate themselves as morally superior to others (Epley \& Dunning, 2000). Moreover, recent theoretical perspectives on self-esteem also argue that self-esteem reflects, at least in part, perspectives of worldview validation (Pyszcynski, Greenberg, Solomon, Arndt, \& Schimel, 2004). As respect can also be seen as a confirmation of us living in a moral community, it may thus also elevate our self-esteem as authentic and dignified human beings.

\section{When does Need Satisfaction versus Moral Principles determine the Value of Respect the Most?}

If respect is to be valued for different reasons (as a means to an end or an end in itself) will there be differences among people who wish to pursue respect for one value or the other? Building upon the idea that people's self can take different forms and consequently affect how people's attention is directed, we put forward the suggestion that the 
reason why respect is important to people is a function of whether their pragmatic versus idealistic self is most salient.

The self can be seen as a multifaceted and dynamic structure containing knowledge about one's own thoughts, attitudes, motives and feelings (Leary, 2001). This view implies that people have different self-representations that can be active at different times and in different situations. Indeed, the self is not uni-dimensional (Markus \& Wurf, 1987). People have distinct selves and each of these selves involves goals, values and beliefs. Once these goals and values are accessible and salient they will energize and direct our actions (Carver, 2001). Moreover, the self is also very dynamic, which means that at any specific point in time or in any specific situation another type of self can be active. As a result, this active type of self will then have specific cognitive, affective, and behavioral consequences (e.g., Lord, Brown, \& Freiberg, 1999). The type of self that is active is usually referred to as the working self-concept (Markus \& Wurf, 1987).

Here, we argue that two specific types of working self-concepts may exert strong effects on the reasons why people value respect. More precisely, we argue that if the pragmatic self is active then people value respect because it satisfies their needs. On the other hand, if the idealistic self is active then people value respect in itself. The pragmatic self has been found to be more sensitive to situational opportunities that can help facilitating actions and the attainment of desirable goals (Kivetz \& Tyler, 2007). The fulfilment of concerns of belongingness and reputation may represent such desirable goals. Moreover, the pragmatic self also is more realistic and tuned in on the moment, that is, when this self-concept is active people focus more strongly on means that may be useful at the present moment (i.e., proximal time perspective; Trope \& Liberman, 2003).

The idealistic self, however, is more occupied with stressing the importance of values and principles above practical considerations. Therefore, this type of working selfconcept makes people more closely related to their sense of true self. As a result, when this type of self is salient then people do not focus so much on the present moment but also more on the longer-term issues (i.e., Trope \& Liberman, 2003).

It has to be noted that the immediate (and self-interested) consequences derived from looking at means satisfying needs at the present moment is often so pervasive that the idealistic self is not always activated (cf. Markus \& Kunda, 1986). This observation may explain, at least to a certain extent, that ethical and moral values are often suppressed and less influential on people's actions. Interestingly, this assumption actually can be seen as reflected in how many of our social interactions nowadays take the form of an economic exchange in which respect is often treated as the exchange of a specific type of resource that needs to be reciprocated immediately (i.e., respect in this context has an hedonic value rather than a moral value).

\section{Conclusion}

To conclude, in the present paper we have described two perspectives that provide two reasons why people care about respect and why it is such a valuable good in our relationships with others. Based on our prior research (the RIS model; De Cremer \& Tyler, $2005 \mathrm{~b}$ ), we first argued that respect is a means to an end. Indeed, receiving respectful 
treatment signals relational appreciation and satisfies important human motives such as belongingness and reputation concerns. A second reason is that respect can also be seen as an end in itself. That is, giving respect is important in our social relationships because it is something that we morally expect and the enactment of respect itself makes us authentic and moral human beings. As a result, respect serves as an important building stone of a moral community. Interestingly, in this analysis we note that the perspective "respect as a means to an end" may be something that is very much a question arising from people's individual needs, whereas the perspective "respect as an end in itself" represents a call from the society as a whole to ensure the morality of the collective we live in. Finally, we argued that the importance of both perspectives in explaining respect effects might be a function of the working self-concept that is active, that is, pragmatic or idealistic self. We hope that the present theoretical contribution may inspire social science researchers to deepen our understanding further to explaining why respect matters and when it may be most needed.

\section{Notes}

1 The attentive reader will notice that these examples only refer to possible negative aspects of respect. This does not imply, however, that there are no positive aspects to respect. In fact, an abundance of examples exist illustrating that employees frequently prefer working in organizations where they are certain that they will receive respect from their employers rather than moving to a competing firm where they definitely will receive higher financial outcomes, but where they are uncertain about receiving respectful treatment. In our introduction, we used primarily examples focusing on people's complaints about the lack of respect because especially under such circumstances it becomes clear that people very much value the presence of respectful treatment (i.e., the lack of respect can be said to loom larger than the presence of respect, see Baumeister et al., 2000).

2 Our definition of respect (as presented in this article) is grounded in the social justice literature, but, of course, other perspectives exist as well. Dillon (http://plato.stanford.edu/ entries/respect/) provides a very detailed account of the different dimensions that the concept of respect entails. In his theoretical account, Dillon refers to respect as a behavior but also as an attitude and feeling. In fact, respect is something that takes place when a subject responds to an object from the perspective that bestowing respect is a good and appropriate thing to do. The object can take different forms such as the self, another person, or nature in itself.

3 Parts of this article were written when the first author was a research fellow at the Kennedy School of Government, Harvard University, which was also partly sponsored by the "Jonge Akademie" of the Royal Dutch Society of Sciences (KNAW).

\section{References}

Aron, A., \& Aron, N. E. (1986). Love as the expansion of self: Understanding attraction and satisfaction. New York: Hemisphere.

Baumeister, R. F. (1982). A self-presentational view of social phenomena. Psychological Bulletin, 91,3-26.

Baumeister, R. F., \& Leary, M. R. (1995). The need to belong: Desire for interpersonal attachments as a fundamental human motivation. Psychological Bulletin, 117, 497-529.

Berscheid, E., \& Reis, H. T. (1998). Attraction and close relationships. In D. T. Gilbert, S. T. Fiske, G. Lindzey (Eds.), The handbook of social psychology (4 ${ }^{\text {th }}$ ed., Vol. 2, pp. 193-281). New York: McGraw-Hill. 
Boeckman, R. J., \& Tyler, T. R. (2002). Trust, respect, and the psychology of political engagement. Journal of Applied Social Psychology, 32, 2067-2088.

Branden, N. (1998). Self-esteem at work. San Fransisco: Jossey-Bass Publishers.

Brockner, J. (1988). Self-esteem at work. Lexington, MA: Lexington Books.

Carver, C. S. (2001). Self-regulation. In A. Tesser \& N. Schwarz (Eds.), Blackwell handbook of social psychology: Intraindividual processes (pp. 307-328). Oxford: Blackwell.

De Cremer, D. (2002). Respect and cooperation in social dilemmas: The importance of feeling included. Personality and Social Psychology Bulletin, 28, 1335-1341.

De Cremer, D. (2003a). Non-economic motives predicting cooperation in public good dilemmas: The effect of received respect on contributions. Social Justice Research, 16, 367-377.

De Cremer, D. (2003b). A relational perspective on leadership and cooperation: Why it matters to care and be fair. In D. van Knippenberg \& M. A. Hogg (Eds.), Leadership and power: Identity processes in groups and organizations (pp. 109-122). London: Sage Publications.

De Cremer, D., \& Leonardelli, G. (2003). Individual Differences in Need to Belong and Cooperation in Social Dilemmas: The Moderating Effect of Group Size. Group Dynamics: Theory, Research, and Practice, 7, 168-174.

De Cremer, Snyder, \& De Witte (2001). The less I trust, the less I contribute (Or not?): The Effects of Trust, Accountability and Self-Monitoring in Social Dilemmas. European Journal of Social Psychology, 31, 93-107.

De Cremer, D., \& Tyler, T. R. (2005a). Am I respected or not? Inclusion and reputation as issues in group membership. Social Justice Research, 18, 121-152.

De Cremer, D. \& Tyler, T.R. (2005b). A Matter of Intragroup Status: The Importance of Respect for the Viability of Groups. In B. Mannix, M. Neale, \& M. Thomas-Hunt (Eds., 2005), Reseach on managing groups and teams (Vol. 7, pp. 1-21). Greenwich, CT: Elsevier Science Press.

De Cremer, D., \& Tyler, T. R. (2005c). Managing group behavior: The interplay between procedural fairness, self, and cooperation. In M. Zanna (Ed.), Advances in Experimental Social Psychology (Vol. 37, pp.151-218). New York: Academic Press.

Duffy, M. K., Shaw, J. D., \& Stark, E. M. (2000). Performance and satisfaction in conflicted interdependent groups: When and how does self-esteem make a difference. Academy of Management Journal, 43, 772-782.

Epley, N., \& Dunning, D. (2000). Feeling "houlier than thou": Are self-serving assessments produced by errors in self- or social prediction? Journal of Personality and Social Psychology, 79, 861-875.

Fehr, E., \& Fischbacher, U. (2003). Third party punishment and social norms. Evolution and Human Behavior, 25, 63-87.

Fehr, E., \& Gächter, S. (2002). Altruistic punishment in humans. Nature, 415, 137-140.

Gailliot, M.T., \& Baumeister, R. F. (in press). Self-esteem, belongingness, and worldview validation: Does belongingness exert a unique influence upon self-esteem. Journal of Research in Personality.

Gaertner, L., Sedikides, C., Vevea, J. L., \& Luzzini, J. (2002). The "I", the "We", and the "When": A meta-analysis of motivational primacy in self-definition. Journal of Personality and Social Psychology, 83, 574-591.

Gardner, W. L., Gabriel, S., \& Diekman, A. (2000) Interpersonal processes. In L. Tassinary, J. Cacioppo, \& G. Berntson (Eds.), The Handbook of Psychophysiology (pp. 643-664). Cambridge, MA: Cambridge Press.

Gardner, W. L., Pickett, C. L., \& Brewer, M. B. (2000). Social exclusion and selective memory: How the need to belong influences memory for social events. Personality and Social Psychology Bulletin, 26, 486-496.

Heuer, L., Penrod, S., Hafer, C. L., \& Cohn, I. (2002). The role of resource and relational concerns for procedural justice. Personality and Social Psychology Bulletin, 28, 1468-1482.

Hill, T. E. (2000). Respect, pluralism, and justice. Oxford: Oxford University Press. 
James, W. (1890). The principles of psychology. New York, NY: Holt.Johnson, D. E., Erez, A., Kiker, D. S., \& Motowidlo, S. J. (2002). Liking and attributions of motives as mediators of the relationships between individuals' reputations, helpful behaviors, and raters' reward decisions. Journal of Applied Psychology, 87, 808-815.

Kivetz, Y., \& Tyler, T.R. (2007). Tomorrow I'll be me: The effect of time perspective on the activation of idealistic versus pragmatic selves. Organizational Behavior and Human Decision Processes, 102, 193-211.

Koper, G., van Knippenberg, D., Bouhuijs, F., Vermunt, R., \& Wilke, H. (1993). Procedural fairness and self-esteem. European Journal of Social Psychology, 23, 313-325.

Kurzban, R., \& Leary, M. R. (2001). Evolutionary origins of stigmatization: The functions of social exclusion. Psychological Bulletin, 127, 187-208.

Lax, D.A., \& Sebenius, J.K (1986). Interests: The measure of negotiation. Negotiation Journal, 2, 73-92.

Leary, M. (2001). The self as a source of relational difficulties. Self and Identity, 1, 137-142.

Leary, M. R., \& Baumeister, R. F. (2000). The nature and function of self-esteem: Sociometer theory. Advances in Experimental Social Psychology, 32, 1-62.

Lind, E. A., \& Tyler, T. R. (1988). The social psychology of procedural justice. New York: Plenum Press.

Lord, R. G., Brown, D. J., \& Freiberg, S. J. (1999). Understanding the dynamics of leadership: The role of follower self-concepts in the leader/follower relationship. Organizational Behavior and Human Decision Processes, 78, 1-37.

Markus, H., \& Kunda, Z. (1986). Stability and malleability of the self-concept. Personality and Social Psychology Bulletin, 51, 858-866.

Markus, H., \& Wurf, E. (1987). The dynamic self-concept: A social psychological perspective. Annual Review of Psychology, 38, 299-337.

McAllister, D. J., \& Bigley, G. A. (2002). Work context and the definition of self: How organizational care influences organization-based self-esteem. Academy of Management Journal, 45, 894-904.

Miller, D. T. (2001). Disrespect and the experience of injustice. Annual Review of Psychology, 52, 527-553.

O'Connell, L. J. (2000). The worlds of religion and psychiatry: Bioethics as arbiter of mutual respect. In J. K. Boehnlein (Ed.), Psychiatry and religion: The convergence of mind and spirit (pp. 145-157). Washington, DC: American Psychiatric Press, Inc.

Pyszcynski, T., Greenberg, J., Solomon, S., Arndt, J., \& Schimel, J. (2004). Why do people need self-esteem? A theoretical and empirical review. Psychological Bulletin, 130, 435-468.

Reis, H. T., Collins, W. A., \& Berscheid, E. (2000). The relationship context of human behavior and development. Psychological Bulletin, 126, 844-872.

Simon, B., \& Stürmer, S. (2003). Respect for group members: Intragroup determinants of collective identification and group-serving behavior. Personality and Social Psychology Bulletin, 29, 183-193.

Simon, B., \& Stürmer, S. (2005). In search of the active ingredient of respect: a closer look at the role of acceptance. Europan Journal of Social Psychology, 35, 809-818.

Simon, B., Lucken, \& Stürmer, S. (2006). The added value of respect: reaching across inequality. British Journal of Social Psychology, 45, 535-546.

Twenge, J. M., Baumeister, R. F., Tice, D. M., \& Stucke, T. S. (2001). If you can't join them, beat them: Effects of social exclusion on aggressive behavior. Journal of Personality and Social Psychology, 81, 1058-1069.

Twenge, J. M., Catanese, K. R., \& R. F. Baumeister (2002). Social exclusion and self-defeating behavior. Journal of Personality and Social Psychology, 83, 606-615.

Trope, Y., \& Liberman, N. (2003). Temporal construal. Psychological Review, 110, 403-421.

Tyler, T. R., Degoey, P., \& Smith, H. (1996). Understanding why the justice of group procedures matter: A test of the psychological dynamics of the group-value model. Journal of Personality and Social Psychology, 70, 913-930. 
Tyler, T. R., \& Lind, E. A. (1992). A relational model of authority in groups. In M. Zanna (Ed.), Advances in Experimental Social Psychology (Vol. 25, pp. 115-191). New York: Academic Press

\section{Authors:}

David De Cremer is Professor of Social Psychology at Tilburg University and director of Center for Justice and Social Decision Making (JuST, www.centerofjust.org). His current research interests are social dilemmas and 2-person games, social justice, trust repair, leadership and power, and behavioral economics. He has edited two books on "Social Psychology and Economics" (Lawrence Erlbaum Associates) and "Advances in the Psychology of Justice and Affect" (Information Age Publishing).

Laetitia B. Mulder is Assistant Professor of Social Psychology at Tilburg University. Her research interests are social decision making, sanctions and rewards, moral norms, compliance, and norm internalization.

\section{Address:}

David De Cremer, Department of Social Psychology, Tilburg University, Center of Justice and Social Decision Making (JuST; www.centerofjust.com), P.O. Box 90153, 5000-LE Tilburg, the Netherlands. Fax: 0031134662067. 